Marcin Jarząbek

[Kraków]

$\bullet \bullet \bullet \bullet \bullet \bullet$

\title{
Rzeczy w opowieściach \\ - sprawozdanie z V Warsztatów Polskiego \\ Towarzystwa Historii Mówionej
}

Wrocławski Rocznik

Historii Mówionej

Rocznik III, 2013

ISSN 2084-0578

Między 18 a 20 października 2013 r. odbyło się w Krakowie piąte już, coroczne spotkanie Polskiego Towarzystwa Historii Mówionej. Miało one miejsce w Instytucie Historii Uniwersytetu Jagiellońskiego oraz gościnnie w Państwowym Muzeum Etnograficznym im. Seweryna Udzieli. Tym razem - zgodnie z pomysłem Marty Kurkowskiej-Budzan - problemem, który zajmował uczestników warsztatów, było miejsce i znaczenie rzeczy (i szerzej - materialności) w historii mówionej. W tym miejscu chciałbym omówić sam przebieg krakowskiego spotkania, podsumować wypływające z niego wnioski oraz przedstawić plany PTHM na najbliższy czas.

Podobnie jak w poprzednich latach Walnemu Zgromadzeniu PTHM towarzyszyły referaty, dyskusje metodologiczne i próby konfrontacji różnych perspektyw, z których patrzymy na historię mówioną. Oprócz nich pojawił się w tym roku element nowy: pierwszego dnia Zjazdu miały miejsce kilkugodzinne warsztaty dla studentów, prowadzone przez członków PTHM i zarazem doświadczone oralistki: Kaję Kaźmierską (Uniwersytet Łódzki), Annę Maciąg (Fundacja Ośrodka „KARTA”) oraz Agatę Zysiak (Stowarzyszenie „Topografie”/Uniwersytet Łódzki). Warsztaty zaplanowane zostały dla trzech różnych grup, w zależności od stopnia doświadczenia w obrębie historii mówionej przez uczestników: od studentów, którzy dopiero 
zaczynają swoją przygodę z historią mówioną, przez tych, którzy zrobili już pierwsze kroki i dalej są zainteresowani słuchaniem ludzkich opowieści, aż po osoby pracujące nad interpretacją wywiadów biograficznych. Zainteresowanie wśród studentów (i nie tylko) historii, socjologii i antropologii, jakim cieszyły się te zajęcia (wzięło w nich udział przeszło 40 osób) sugeruje, że tego typu działania warto na stałe włączyć w harmonogram corocznych spotkań PTHM w różnych miastach Polski.

Drugi dzień Walnego Zjazdu PTHM przeznaczony był na dyskusje i warsztaty, które odbywały się w Muzeum Etnograficznym na krakowskim Kazimierzu. W panelu dyskusyjnym „Przejdźmy do rzeczy: o biografiach i przedmiotach w badaniach historyczno-społecznych" spotkały się więc ze sobą różne podejścia do relacji między rzeczami a opowiadaniem: podejście muzealnicze, podejście antropologiczne, podejście socjologiczne i wreszcie podejście edukacyjne. Monika Sznajder z Muzeum Etnograficznego przedstawiła projekty realizowane przez tę instytucję, w których bezpośredni kontakt (zarówno muzealnika, jak i przede wszystkim - zwiedzającego) z rzeczą z przeszłości (w muzeum w formie eksponatu) jest doświadczeniem niezwykle istotnym: tak podczas pracy w terenie, jak i na wystawach oraz w działaniach edukacyjnych. Znaczenie materialności dla muzeum dość wyraźnie pokazał przykład tak z pozoru niematerialnej rzeczy jak zdjęcie (istniejące w formie slajdu, szklanego pozytywu, celuloidowego negatywu, w albumie z opisem, w ramce na ścianie, w pudełku po butach itp.). Był to ważny - jak sądzę - głos w kontekście powszechnego dziś przyjęcia narracyjnej koncepcji wystawy muzealnej, w której autentyczny eksponat przestał być elementem obowiązkowym.

Właśnie wokół samego pojęcia autentyczności rzeczy i doświadczenia zbudowane było wystąpienie Ewy Klekot z Uniwersytetu Warszawskiego. Podstawową wartością tych rzeczy, które uznajemy za pamiątki, zabytki, a więc przedmioty służące ustanawianiu ciągłości rzeczywistości społecznej, jest właśnie ich autentyczność, czyli to, że dana rzecz daje możliwość bezpośredniego doświadczenia przeszłości. Takie rozumienie jest, według warszawskiej antroplożki, zakorzenione w tzw. paradygmacie ekspresywistycznym, który zakłada, że autentyczne przeżycie czegoś i emocje temu towarzyszące stały się od czasów romantyzmu kluczowe dla narodzin i rozwoju nowoczesnej tożsamości. Chęć przeżycia autentycznego doświadczenia ma więc wyjaśniać popularność grup rekonstrukcji historycznej, odbudowywania zabytków z ich autentycznymi wnętrzami czy wreszcie popularność samej historii mówionej. Na koniec swego wystąpienia Ewa Klekot - za Tomem 
Selwynem - zaproponowała również rozróżnienie na chłodny i ciepły aspekt autentyczności, ze względu na to właśnie, jaką „temperaturę” przeżycie daje. Ten pierwszy (chłodny) to autentyczność samego przedmiotu, materii (np. autentyczny miecz z XV w.), potwierdzona opinią („certyfikatem”) „eksperta”. Ten drugi (ciepty) odnosi się do autentyczności opowieści o czymś (np. świadectwo byłego więźnia obozu koncentracyjnego). Choć autentyczne przedmioty są w historii mówionej traktowane (szczególnie przez rozmówców) jako uwiarygodnienie opowieści, to jednak sama opowieść ma i bez nich większą siłę przekazu doświadczenia niż same przedmioty.

Nieco inne spojrzenie zaproponowała Anna Wylegała (IFIS PAN): dla niej zarówno rzeczy, jak i biografie są "narzędziami do badania rzeczywistości społecznej”, ponieważ pozwalają zrozumieć różne wymiary tego samego badanego świata. Było to więc przedstawienie swoistego holistycznego podejścia do historii mówionej, w którym rzeczy mają swoje znaczenie i miejsce w wywiadach biograficznych (czasem jako „haczyki”, na których zawieszone są nowe wątki opowieści, wywołane właśnie przez jakiś przedmiot), a same narracje biograficzne pozwalają zrozumieć szerszy kontekst badanego problemu (w tym odwieczny problem nauk społecznych: czy to, co ważne dla nas, jest też istotne dla „badanych”). Jeśli socjologia jakościowa poszłaby właśnie w stronę takiego holistycznego badania rzeczywistości społecznej, jaką zaproponowała warszawska socjolożka, to - jak sądzę - byłoby to z dużą korzyścią zarówno dla socjologii, jak i dla dialogu z badaczami innych dyscyplin nauk społecznych i humanistycznych.

Zastosowanie takiego właśnie rozumienia relacji historii mówionej i przedmiotów było z kolei przedmiotem wystąpienia Wioletty Wejman z Bramy Grodzkiej-Teatru „NN”. Przygotowany przez lubelski ośrodek internetowy projekt edukacyjny rekonstrukcji mieszkania z czasów PRL „składa się" z przedmiotów, które znajdowały się w opowieściach rozmówców nagranych przez Bramę. Jest więc wyposażenie, meble i detale, jakie znajdować się mogły w zwykłym M3 z lat 70. Nie zabraknie w nim też elementów życia opozycyjnego (rozmówcami twórców wystawy byli tutaj często byli opozycjoniści z regionu lubelskiego): „bibuły”, ulotek czy powielacza. W tym przedsięwzięciu teoretyczne rozważania o chłodnym i ciepłym aspekcie znaleźć mogły swoją praktyczną syntezę: na potrzeby edukacyjne stworzono wirtualne miejsce wyposażone w autentyczne przedmioty, które swoje uprawomocnienie mają w autentycznych opowieściach.

Co ciekawe, ta właśnie kwestia wzbudziła najwięcej pytań w trakcie dość burzliwej dyskusji po wspomnianych wystąpieniach. W kontekście tego, co 
jest, a co nie jest „bibułą”, Janusz Barański zwrócił uwagę na jeszcze jedno rozróżnienie: autentyczności faktu (tj. jego prawdziwości, zgodności z rzeczywistością) i autentyczności przeżycia (opowiadający jest przekonany o prawdziwości czegoś). Inni dyskutanci (m.in. Grażyna Kubica-Heller, Marta Kurkowska-Budzan, Barbara Klich-Kluczewska, Piotr Filipkowski) zwracali uwagę na problem bardzo różnorodnego stosunku ludzi do rzeczy, który komplikuje też działania badawcze czy archiwizacyjne (choćby w archiwach społecznych). Do konkluzji dojść się nie udało, ale sądzę, że ilość inspirujących myśli, które padły w tej sobotniej dyskusji wystarczy na co najmniej kilka projektów badawczych i społecznych.

W kolejnej części zebrani mieli możliwość zapoznać się z imponującą działalnością białoruskiego środowiska historii mówionej, którą przedstawił prof. Aliaksander Smalianczuk. Mimo mało sprzyjających warunków (a właściwie - zupełnego ich braku) od kilku już lat grupie historyków, socjologów i antropologów udaje się z dużym powodzeniem tworzyć na Białorusi historię mówioną: niezależną, a czasem wręcz biegunowo odmienną od historii oficjalnej tego kraju. Na stronie internetowej www.nashapamiac.org znajduje się w tej chwili 50 kolekcji, liczących łącznie 600 nagrań. Wartość tych nagrań jest unikatowa także z polskiego punktu widzenia, bo dotyczą one np. pamięci o wojnie 1939 r. po obu stronach dawnej granicy lub o głodzie z 1947 r. Co także warte odnotowania - wszystkie te nagrania w całości są dostępne online.

Spotkanie w Muzeum Etnograficznym zwieńczyły warsztaty pracy z rzeczami. Ich ideą było to, by historycy, zajmujący się oral history sami spróbowali analitycznym okiem (i innymi zmysłami) przyjrzeć się przedmiotom i ich historiom. Wybrane muzealne eksponaty posłużyły w tym wypadku do postawienia im szeregu pytań. Co istotne, każdy z nich łączył się wprost z jakąś historią, także z historią stania się muzealnym eksponatem. Sądzę, że było to pouczające doświadczenie, nie tylko dla muzealników.

W niedzielę, w ostatni dzień krakowskiego Zjazdu PTHM, odbyło się jego Walne Zgromadzenie. Udało się wybrać nowe władze Towarzystwa, które pokierują nim przez najbliższe dwa lata. W skład Zarządu weszli: Magda Szymańska-Szwąder jako skarbnik, Katarzyna Bock jako sekretarz, Karolina Żłobecka jako wiceprezes i Anna Wylegała jako wiceprezes oraz piszący te słowa jako prezes. Prócz spraw personalnych dużą część posiedzenia poświęcono planom PTHM na kolejne lata działalności. Poza organizacją kolejnych warsztatów, w 2014 r. istotnym zadaniem dla Towarzystwa jest przygotowanie sesji poświęconej historii mówionej w ramach 
XIX Powszechnego Zjazdu Historyków w Szczecinie. Podjęliśmy również pierwsze kroki do organizacji w $2015 \mathrm{r}$. międzynarodowej konferencji w Łodzi (we współpracy z Instytutem Socjologii UŁ), która byłaby okazją do pogłębienia współpracy i wymiany doświadczeń z badaczami i praktykami historii mówionej z sąsiednich krajów. Prócz tego czeka nas także wypracowanie polskich rekomendacji etycznych i metodologicznych, które mogłyby być użyteczne przy realizacji różnych projektów historii mówionej, szczególnie tych realizowanych oddolnie. To dla PTHM cel bardzo istotny, choć jego pełna realizacja wymagać będzie zapewne wiele czasu i nakładów pracy oraz szerokich konsultacji w środowisku polskich oralistów. Ufam jednak, że będzie to możliwe właśnie dzięki wsparciu ze strony samych członków PTHM. Wydaje mi się bowiem, że spośród wielu możliwych misji i celów, które Towarzystwo mogłoby sobie stawiać, najpilniejszym jest w tej chwili obranie roli organizacji „sieciującej” (np. poprzez periodyczny Newsletter), tworzącej pomocne rękom endacje i standardy dla historii mówionej i wspierającej w ten sposób rozwój historii mówionej w Polsce. 